\title{
Studi Kelayakan Dan Perancangan Serta Implementasi Turbin Pada Proyek PLTMH Di Kabupaten Sleman Yogyakarta
}

\author{
Achmad Tarmizi ${ }^{1}$, Herry Wardono ${ }^{2}$ \\ ${ }^{1}$ Pemerintah Daerah Kabupaten Ogan Komering Ulu \\ ${ }^{1}$ Jl. Kemelak Bindung Langit, Batu Raja Timur, Ogan Komering Ulu, Sumatera Selatan 32111 \\ 1achmadtarmizi780@gmail.com
}

Intisari-Pemerintah Daerah Kabupaten Sleman akan membangun PLTMH dengan memanfaatkan potensi tenaga air di desa Girikerto yang merupakan salah satu sumber energi terbarukan. Penelitian ini didasarkan pada hasil studi kelayakan yang dilakukan penulis dengan melakukan studi lapangan untuk mengambil data-data dilokasi dengan memperhatikan aspek teknis, ekonomis dan sosial, kemudian dilakukan studi literatur dan analisis data untuk menentukan jenis turbin dan karakteristik yang paling tepat untuk PLTMH dilokasi tersebut. Dari hasil analisis data dan dengan melakukan perhitungan yang teliti serta dengan memperhatikan kondisi lokasi proyek PLTMH tersebut, turbin yang paling tepat untuk digunakan adalah turbin tipe Cross Flow. Turbin ini selain memiliki konstruksi yang sederhana, dapat pula didesain untuk kapasitas yang cukup besar dan lebih mudah dalam proses fabrikasi. Hasil lain yang diperoleh yaitu nilai perbandingan benefit dengan cost sebesar 0,79 (kurang dari 1). Hal ini berarti bahwa pembangunan PLTMH ini dinilai tidak ekonomis, tapi dengan daya yang mampu dihasilkan sebesar $10,58 \mathrm{~kW}$ tentunya akan mampu menerangi dan menyuplai listrik (manfaat yang sangat besar) bagi puluhan warga desa Girikerto.

Kata kunci: PLTMH Sleman, Mikrohidro, turbin cross flow.

Abstract-The Regional Government of Sleman Regency will build a PLTMH by utilizing the potential of hydropower in Girikerto village, which is one of the renewable energy sources. This research is based on the results of a feasibility study conducted by the author by conducting a field study to retrieve location data by paying attention to technical, economic and social, then a literature study and data analysis are carried out to determine the type of turbine and the most appropriate characteristics for the PLTMH at that location. From the results of the data analysis and by conducting careful calculations and taking into account the conditions of the PLTMH project location, the most appropriate turbine to be used is the turbine Cross Flow type. Besides having a simple construction, this turbine can also be designed for a large enough capacity and is easier to fabricate. Another result obtained is the value of the ratio of benefits to costs of 0.79 (less than 1). This means that the construction of this PLTMH is considered uneconomic, but with the power it can generate at $10.58 \mathrm{~kW}$, it will certainly be able to illuminate and supply electricity (a huge benefit) for dozens of Girikerto villagers.

Keywords : PLTMH Sleman, Microhydro, Cross flow turbine

\section{PENDAHULUAN}

Energi listrik telah menjadi kebutuhan pokok dan memainkan peranan yang penting dalam kehidupan manusia. Di Indonesia, PLN baru mampu menyuplai 53\% dari total kebutuhan listrik masyarakat, sementara $47 \%$ penduduk Indonesia hidup di daerah yang tidak terjangkau jaringan listrik. Hal ini dikarenakan keterbatasan infrastruktur dan kapasitas pembangkit listrik yang tersedia, padahal sumber energi pembangkit tidak semata-mata dari bahan bakar fosil, seperti halnya pemakaian solar dan batubara dari PLTD dan PLTU.

Sebenarnya Pembangkit Listrik Tenaga Mikrohidro (PLTMH), memiliki potensi besar untuk dikembangkan di daerah-daerah pedesaan 
yang belum terjangkau oleh infrastruktur PLN. PLTMH memanfaatkan aliran sungai setempat, yaitu dengan cara mengalihkan sebagian aliran air menuju turbin, lalu selepas dari turbin, air dikembalikan kealiran semula, sehingga keberadaannya tidak berdampak pada lingkungan setempat.

Kabupaten Sleman terletak di bagian wilayah utara Propinsi DI Yogyakarta, dengan batas sebelah utara Kabupaten Boyolali Propinsi Jawa tengah, sebelah timur dengan Kabupaten Klaten Propinsi Jawa Tengah, sebelah selatan dengan kabupaten Bantul dan kota Yogyakarta Propinsi DI Yogyakarta, sebelah barat dengan Kabupaten Kulon Progo Propinsi DI Yogyakarta dan Kabupaten Magelang Propinsi Jawa Tengah. Secara geografis Kabupaten Sleman terletak pada $7^{0} 34^{\prime} 51^{\prime \prime}$ dan $7^{0} 47^{\prime} 03^{\prime \prime}$ Lintang selatan serta pada $107^{\circ} 15^{\prime} 03^{\prime \prime}$ an $100^{\circ} 29^{\prime} 30^{\prime \prime}$ Bujur Timur.

Luas wilayah Kabupaten Sleman adalah 57.482 Ha yang kurang lebih $18 \%$ dari luas seluruh Propinsi Daerah Istimewa Yogyakarta, Secara administratif Kabupaten Sleman terbagi menjadi 17 Kecamatan, 86 Desa dan 1.212 Dusun, dan terbagi atas 3 wilayah yaitu: Wilayah Sleman Timur, Sleman Tengah dan Sleman Barat. Wilayah SlemanTimurmeliputi 6 Kecamatan yakni Prambanan, Kalasan, Berbah, Depok, Ngemplak, dan Cangkringan. Wilayah SlemanTengah meliputi 6 Kecamatan yakni Mlati, Sleman, Tempel, Turi, Pakem, dan Ngaglik. Wilayah Sleman Baratmeliputi 5 kecamatan yakni Moyudan, Godean, Minggir, Seyegan dan Gamping. Untuk membantu pelaksanaan pemerintah desa di Kab.Sleman terdapat 1.212 dusun, 2.886 RW dan 6.961 RT. Dengan mempertimbangkan status Kabupaten Sleman sebagai hitherland dari kota Yogyakarta maka dari 86 desa yang ada 27 desa dikategorikan sebagai desa pedesaan dan 59 desa merupakan desa perkotaan.

Luas wilayah kabupaten Sleman 57.482 Ha sebagian besar 45,31 \% dipergunakan sebagai lahan pekarangan, lahan tegalan $9,06 \%$ dan untuk guna lahan yang lain sebesar 14,86\% termasuk didalamnya penggunaan jalan, sungai/selokan, rawa, wedi kengser dan sebagainya.
Penduduk Kabupaten Sleman pada tahun 1990 sebanyak 754.750 jiwa dan tahun 2000 meningkat menjadi 850.176 jiwa dengan pertumbuhan penduduk sebesar $1,43 \%$, dan angka kepadatan penduduk 1.479 jiwa $/ \mathrm{km}^{2}$. Menurut registrasi penduduk sampai pertengahan tahun 2001 jumlah penduduk Kabupaten Sleman 856.558 (naik $0,84 \%$ ) yang terdiri dari 423.333 jiwa penduduk laki-laki dan 433.225 jiwa penduduk wanita.

Pertumbuhan penduduk di Kabupaten Sleman dari tahun ke tahun diupayakan untuk dikendalikan. Pada tahun 2000 pertumbuhan penduduk Sleman sebesar 0,1078\%/tahun, menurun 0,6722\% dibanding tahun sebelumnya. Kepadatan penduduk Kabupaten Sleman rata-rata 1.490 orang per $\mathrm{km}^{2}$. Kepadatan penduduk yang tertinggi terdapat di Kecamatan Depok yakni 3.102 orang per $\mathrm{km}^{2}$.

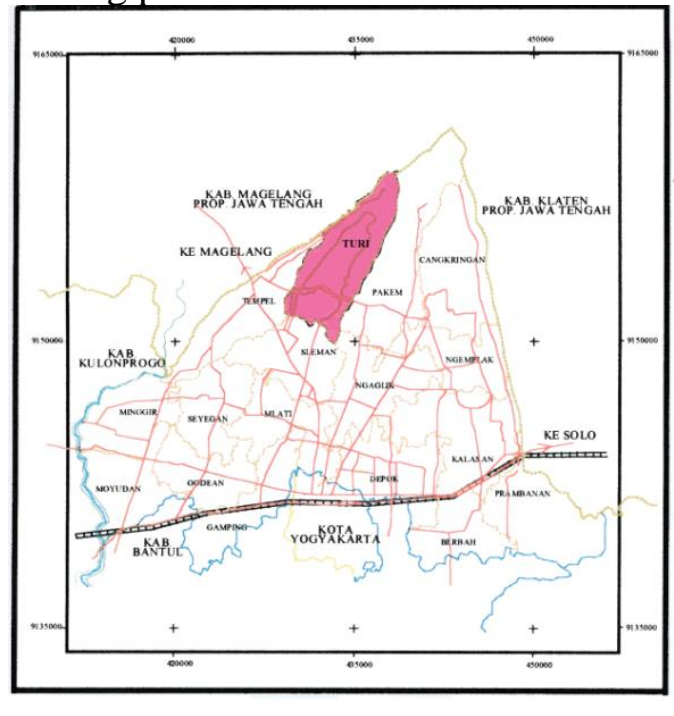

Sumber : Kompilasi data kecamatan Turi

Gambar 1. Peta Kabupaten Sleman

Oleh karena PLTMH kebanyakan dibangun didaerah-daerah pelosok, yang memiliki potensi air, maka dalam pemakaian turbin air para perancang banyak yang menyarankan bahwa turbin air tipe Cross Flow cocok untuk PLTMH, dikarenakan fasilitas didaerah pelosok sangat terbatas dan juga turbin air tipe Cross Flow ini lebih mudah dalam fabrikasi.

Mengingat tingkat kebutuhan energi listrik terus mengalami kenaikan setiap tahunnya, sehingga penyediaan energi listrik harus pula ditingkatkan agar terjadi keseimbangan antara 
kebutuhan dan penyediaan energi listrik. Tingkat kebutuhan ini menjadi salah satu pertimbangan utama dalam pembangunan pembangkit tenaga listrik yang baru maupun peningkatan kapasitas daya pada pembangkit tenaga listrik yang sudah ada.

Permasalahan-permasalahan yang dihadapi pada studi kelayakan dan perancangan serta implementasi turbin pada proyek mikrohidro di kabupaten sleman propinsi DI Yogyakarta, adalah:

1. Studi kelayakan pada lokasi proyek, sangat diperlukan untuk mengenali secara pasti kondisi lokasi apakah layak dibangun proyek PLTMH.

2. Hasil studi kelayakan teknis dikaji untuk menentukan jenis turbin yang tepat digunakan, kemudian dilakukan perancangan turbin yang dipakai.

3. Hasil perancangan turbin, diiplementasikan pada proyek PLTMH kabupaten Sleman Yogyakarta.

Hasil penelitian ini sangat berguna sebagai acuan untuk implementasi pemakaian turbin yang tepat pada pembangkit listrik tenaga Mikrohidro di Kabupaten Sleman Propinsi DI Yogyakarta. Selain itu, hasil penelitian ini diharapkan menjadi referensi bagi kegiatan penelitian berikutnya.

Penelitian ini bertujuan meneliti dan merancang jenis turbin yang sesuai untuk diimplementasikan pada proyek pembangunan PLTMH di Kabupaten Sleman, sehingga dapat menghasilkan daya yang optimal, sesuai dengan hasil studi kelayakan dengan memperhatikan aspek teknis, ekonomis dan sosial.

\section{TINJAUAN PUSTAKA}

\subsection{Tinjauan Pustaka}

Turbin Cross Flow dikenal oleh masyarakat Amerika setelah Mockmore dan Merryfield, pada tahun 1949, mengintroduksikan terjemahan bebas kertas kerja Banki. Mockmore dan Merryfield juga melakukan studi mengenai turbin Banki dengan mengadakan experimen, mereka menggunakan model yang memiliki ukuran runner (roda turbin) dengan diameter 13,1 inci, lebar 12 inci, dan perbandingan antara diameter luar dan diameter dalam 0,66. Jumlah sudu yang dipilih adalah sebanyak 20 buah. Efisiensi turbin yang mereka dapatkan sebesar $68 \%$ pada putaran poros turbin $270 \mathrm{rpm}$.

2.2. Landasan Teori

2.2.1. Studi Kelayakan

Studi kelayakan Proyek adalah suatu penelitian tentang dapat tidaknya suatu proyek dilaksanakan dengan berhasil. Studi kelayakan merupakan penilaian yang menyeluruh untuk menilai keberhasilan proyek, oleh karenanya semua faktor harus dipertimbangkan dalam suatu analisis terpadu, keberhasilan proyek memiliki pengertian yang berbeda antara pihak yang berorientasi laba dan pihak yang tidak berorientasi laba semata.

Studi kelayakan sangat penting artinya bagi manajemen. Hal ini disebabkan oleh fungsifungsi yang terdapat di dalamya, yaitu sebagai perencanaan, pengorganisasian, pengadaan staf, pengarahan dan pengawasan, kelima fungsi itu selalu ada dalam proses manajemen.Studi kelayakan adalah merupakan salah satu bentuk peramalan yang menghadapi ketidakpastian. Sekalipun sudah memperhitungkan resiko bisnis maupun resiko keuangan namun tetap harus waspada dan tidak menganggap studi kelayakan sebagai sesuatu yang mutlak akan terjadi. Dalam penilaian proyek sehubungan dengan pengambilan keputusan dilaksanakan suatu proyek atau tidak, terdapat beberapa kriteria keputusan. Pada dasarnya kriteria keputusan tersebut terdiri atas dua pendekatan yaitu :

1. Pendekatan faktor-faktor dalam proyek secara individu.

2. Pendekatan nilai proyek secara keseluruhan.

Pada prinsipnya melakukan studi kelayakan dimaksudkan untuk menghindari dilaksanakannya proyek-proyek, baik yang bertujuan mencari laba maupun bukan pencari laba yang tidak memberikan keuntungan dan kemanfaatan.

Usaha pencari laba dan usaha bukan pencari laba memiliki perbedaan dalam penilaian proyeknya masing-masing. Usaha pencari laba biasanya ditangani swasta, memiliki tekanan pada besarnya keuntungan yang akan diperoleh oleh 
proyek yang bersangkutan dimasa yang akan datang. Sedangkan usaha bukan pencari laba memiliki penekanan penilaian pada besarnya kemanfaatan yang akan diperoleh masyarakat dimasa yang akan datang.

2.2.2. Turbin Air

\subsubsection{Turbin Impuls}

Turbin impuls adalah suatu turbin air dimana seluruh energi air jatuh, diubah menjadi energi kinetis sebelum mencapai roda-roda turbin. Pada umumnya air dialirkan melalui nozel untuk mendapatkan energi kecepatan air yang tinggi, selanjutnya menumbuk mangkok-mangkok yang terpasang kuat pada sekeliling roda turbin. Energi kecepatan air yang menumbuk mangkok (Buckets) mengakibatkan roda turbin (runner) berputar. Putaran poros runner dihubungkan pada poros generator oleh sebuah kopling.

\subsubsection{Turbin Reaksi}

Turbin reaksi adalah suatu turbin dimana proses perubahan energi potesial menjadi energi kinetis terjadi pada sudu penggerak dan sudu jalan (runner). Sudu jalan seluruhnya terendam dalam air, sehingga tekanan air sebelum sudu penggerak lebih besar dan tekanan air saat meninggalkan runner kecil sekali yaitu kurang dari satu atmosfir. Sementara itu, kecepatan aliran dalam pipa isap akan berkurang dan tekanannya akan kembali naik, sehingga air bisa dialirkan keluar lewat saluran air dibawah dengan tekanan seperti pada keadaan sekitarnya.

\subsubsection{Turbin Cross Flow}

Turbin air Cross Flow memiliki konstruksi yang sederhana dan dapat di desain untuk kapasitas yang cukup besar. Para perancang tenaga pembangkit sistem tenaga air menggolongkan turbin ini sebagai turbin air yang paling cocok untuk teknologi menengah, pada umumnya turbin ini dipertimbangkan sebagai turbin impul, yang terdiri dari sebuah runner dan nozzle. Runner turbin jenis ini berbentuk sangkar tupai, sudu-sudu runner dipasang tetap diantara kedua piringan yang disangga oleh poros.

Prinsip kerja dari turbin Cross Flow adalah sebagai berikut : air yang keluar dari nozzle masuk kerunner menumbuk sudu-sudu tingkat pertama dan kemudian air tersebut keluar dari lorong. Sudu-sudu tingkat pertama lalu melewati ruang kosong dalam runner yang selanjutnya menumbuk sudu-sudu tingkat kedua dan akhirnya air itu keluar dari lorong sudu-sudu tingkat kedua menuju kolam bawah.

Jalannya penelitian dengan melakukan survey awal lapangan keseluruh kecamatan di kabupaten Sleman, mengumpulkan data-data dari instansi terkait dan literatur tentang semua yang berhubungan dengan PLTMH. Setelah itu melakukan studi kelayakan dan survey detail pada salah satu lokasi, untuk mengetahui kelayakan pembangunan proyek pada lokasi tersebut.Selanjutnya peneliti melakukan analisis data yang didapat untuk menentukan dan merancang jenis turbin yang tepat digunakan pada pembangunan PLTMH di Kabupaten Sleman, hasil rancangan turbin diimplementasikan pada proyek. Mengingat kegiatan penelitian ini adalah salah satu kegiatan yang menyatu dengan proyek, maka dapat dengan cara dibuat sendiri ataupun dengan melakukan pemesanan pada pihak yang memproduksi turbin cross flow.

Untuk membangun proyek PLTMH, perlu melalui beberapa tahapan persiapan, tahapan paling awal adalah bagaimana mencari dan menemukan adanya potensi air yang dapat dijadikan tempat pembangunan PLTMH di suatu lokasi. Potensi tersebut secara kasar/awal dapat diperkirakan melalui tahapan yang biasa disebut " study meja" (desk study). Studi meja ini adalah studi pendahuluan yang dilaksanakan pada ruang kerja. Selanjutnya melakukan survei lapangan, mengumpulkan data-data dari instansi terkait dan literatur tentang semua yang berhubungan dengan PLTMH dan lokasi yang dipilih. Setelah itu melakukan studi kelayakan dilanjutkan dengan analisis data yang didapat untuk menentukan jenis turbin yang tepat digunakan pada pembangunan PLTMH di Kabupaten Sleman.

Setelah melakukan studi kelayakan dilapangan, selanjutnya dilakukan perancangan turbin berdasarkan hasil survei lapangan dengan data teknis yang didapat di lokasi yang dipilih

Implementasi pengunaaan turbin pada proyek dapat dilakukan dengan dua cara yakni turbin hasil rancangan dibuat langsung di MST 
Mikrohidro UGM ataupun dapat dilakukan pemesanan pada pihak yang memproduksi turbin cross flow. Pada penelitian ini yang dimaksud penulis dengan implementasi adalah hasil rancangan turbin yang dilakukan penulis, dipakai oleh proyek sebagai acuan pembuatan turbin, oleh karena itu, pada dasarnya setelah dilakukan penanda tanganan keputusan Pemimpin Proyek pengembangan energi daerah istimewa Yogyakarta no : 178 / PPE / V / 2003 tanggal 12 Mei 2003, tentang Penetapan MST MIKROHIDRO Universitas Gadjah Mada sebagai penyedia jasa konsultasi perencanaan pembangunan PLTMH tahun 2003, maka sisi implementasi pada tulisan ini telah tercapai, tetapi untuk menambah pengetahuan, penulis akan ikut serta dalam proses awal pembuatan turbin tersebut.

\subsubsection{Perancangan Turbin Crossflow PerancanganTurbin}

1. DayaTeoritisTurbin

Dari data sipil diketahui bahwa :

Debit air (Q) direncanakan $=0,28 \mathrm{~m}^{3} / \mathrm{s}$

Tinggi jatuh air efektif $(\mathrm{H})=5,5$ meter

Daya teoritis turbin dapat dihitung dengan rumus sebagai berikut :

$$
\begin{aligned}
& \mathbf{P}=\mathrm{g} \cdot \mathbf{Q} \cdot \mathbf{H} . \eta_{\mathrm{t}}(\mathrm{kW}) \\
& \text { dimana : } \\
& \mathrm{g}=\text { percepatangravitasi }\left(9,81 \mathrm{~m} / \mathrm{s}^{2}\right) \\
& \mathrm{Q}=\text { Debit air }\left(0,28 \mathrm{~m}^{3} / \mathrm{s}\right) \\
& \mathrm{H}=\text { Tinggi jatuh air }(5,5 \mathrm{~m}) \\
& \eta_{\mathrm{t}}=\text { Effisiensi total diambil } 70 \%
\end{aligned}
$$

Maka :

$$
\begin{aligned}
& \mathrm{P}=9,81 . \mathrm{H}_{\mathrm{ef}} \cdot \mathrm{Q} \cdot(1 / 0.746) \cdot \Delta \mathrm{t} \cdot(\mathrm{HP}) \\
& =9,81.5,5 \cdot 0 \cdot 28 \cdot(1 / 0,746) \cdot 0,70 \\
& =14,175 \mathrm{HP}
\end{aligned}
$$

dimana $1 \mathrm{HP}=745,7$ watt $\approx 746$ watt $=0,746$

kW $\quad$ sehingga : $\mathrm{P}=14,175.0,746$

$$
\mathrm{P}=10,58 \mathrm{~kW} \approx 11,0 \mathrm{~kW}
$$

\section{PemilihanJenisTurbin}

Sebuah turbin dipilih dan dirancang sesuai dengan kondisi tertentu agar beroperasi pada efisiensi yang tinggi. Kecepatan spesifik dapat digunakan untuk pemilihan jenis turbin.
Kecepatan spesifik adalah kecepatan putaran turbin yang sejenis secara geometris untuk menghasilkansatu satuan head pada effisiensimaksimum. Dengan demikian akan memberikan karakteristik dari kemampuan turbin dengan output maksimum pada kecepatan tertinggi yang mungkin dicapai. Kecepatan spesifik dinyatakan dengan persamaan :

$$
\mathrm{Ns}=\frac{\mathrm{NP}^{1 / 2}}{\mathrm{H}^{5 / 4}}
$$

dimana :

$\mathrm{N}=$ Kecepatan putar turbin (rpm), Kecepatan putar generator direncanakan $1400 \mathrm{rpm}$.

Dengan angka transmisi i $=8$ maka kecepatan putar turbin $\mathrm{N}=175 \mathrm{rpm}$.

$\mathrm{P}=$ Daya turbin dalam HP $(14,18 \mathrm{HP})$,

$\mathrm{H}=$ Tinggi jatuh air (5,5 meter)

Maka :

$$
\begin{aligned}
& \mathrm{Ns}=\frac{175 \times(14,18)^{1 / 2}}{(5,5)^{5 / 4}} \\
& \mathrm{Ns}=78,24
\end{aligned}
$$

Tabel 1 Kecepatan Spesifik untuk Berbagai Tipe Turbin

\begin{tabular}{|l|c|}
\hline \multicolumn{1}{|c|}{ TipeTurbin } & KecepatanSpesifik (Ns) \\
\hline Pelton & $12-30$ \\
Turgo & $20-70$ \\
Crossflow & $20-80$ \\
Francis & $80-400$ \\
Propeller dan & $340-1000$ \\
Kaplan & \\
\hline
\end{tabular}

Sumber : Inversin Allen R, 1986

Dari tabel di atas dengan Ns $=78,245$ maka dapat dipilih turbin jenis Crossflow (aliran silang).

Cara lain Pemilihan Jenis Turbin adalah :

Kecepatan spesifik turbin aliran melintang

(Cross Flow) adalah :

$$
\mathrm{n}_{\mathrm{s}}(\mathrm{rpm}, \mathrm{HP}, \mathrm{m})=193 \mathrm{~N}_{\mathrm{s}}
$$

dalam perencanaan $\mathrm{n}_{\mathrm{s}}$ ditetapkan $=$ 78,24

sehingga :

$\mathrm{N}_{\mathrm{s}}=\mathrm{n}_{\mathrm{s}} / 193$

$78,24 / 193=0,40538 \approx 0,41$ 
Harga Putaran Turbin (n)

$$
\begin{aligned}
& \mathrm{n}_{\mathrm{S}}=\frac{\mathrm{n} \cdot \sqrt{\mathrm{P}}(H P)}{\mathrm{H}^{5 / 4}}(4 \cdot 4) \\
& 78,24=\frac{\mathrm{n} \cdot 14,18^{1 / 2}}{5,5^{5 / 4}} \\
& \quad \begin{array}{l}
78,24=\mathrm{n} \cdot 0,44707 \\
\mathrm{n} \quad=175,006 \mathrm{rpm} \approx 175 \mathrm{rpm}
\end{array}
\end{aligned}
$$

\section{Penetapan jenis turbin}

Dari $\mathrm{n}_{\mathrm{s}}$ turbin dan $\mathrm{n}$ turbin tersebut diatas :

1) Menurut tabel kecepatan spesifik, jika $n_{s}$ berada diantara $20-80$,

2) Mengacu pada Tabel Klasifikasi turbin berdasarkan kecepatan normal turbin , jika $\mathrm{n}$ berada diantara 60-1000 rpm,

3) Untuk $\mathrm{N}_{\mathrm{s}}=0,1$ s.d. 0,6. maka dapat ditetapkan, bahwa dengan $\mathrm{Q}$ $=0,28 \mathrm{~m}^{3} / \mathrm{dt}$ dan $\mathrm{H}_{\mathrm{ef}}=5,5 \mathrm{~m}$ dalam perencanaan PLTMH ini menggunakan turbin Cross Flow.

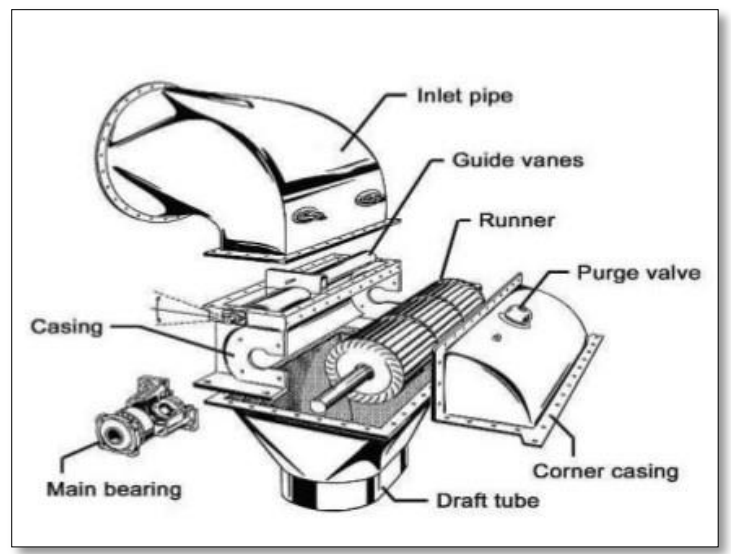

Gambar 2 Konstruksi Turbin Cross Flow Sumber:https://www.slideshare.net/Birink/makalah-primemover.Diakses tanggal: 13 November 2019

\section{Perhitungan Diameter}

a. Kecepatan Air Masuk Turbin Kecepatan air masuk turbin dihitung berdasarkan rumus sebagai berikut: $\mathrm{V}_{1}=\mathrm{C}_{\mathrm{v} \cdot} \cdot \sqrt{2 \cdot \mathrm{g} \cdot \mathrm{H}}(4.5)$ dimana :

$\mathrm{V}_{1}=$ kecepatan air masuk turbin $(\mathrm{m} / \mathrm{dt})$ $\mathrm{g}=$ percepatan gravitasi $\left(9,81 \mathrm{~m} / \mathrm{dt}^{2}\right)$

$\mathrm{H}=$ tinggi jatuh air efektif $(5,5 \mathrm{~m})$

$\mathrm{C}_{\mathrm{v}}=$ nilai koefisien kecepatan air adalah sebesar 0,985
$\mathrm{V}_{1}=0,985 \cdot \sqrt{2.9,81 \mathrm{~m} / \mathrm{dt}^{2} \cdot 5,5 \mathrm{~m}}=10,232$ $\mathrm{m} / \mathrm{dt}$

b. Kecepatan Keliling Sisi Masuk Rotor/Kecepatan Tangensial ( $\left.\mathrm{U}_{1}\right)$ Untuk turbin air jenis aliran melintang (Cross Flow), kecepatan tangemsial runner dapat dihitung dengan menggunakan rumus :

$\mathrm{U}_{1}=\mathrm{K} \mathrm{U}_{1} \cdot \sqrt{2 . \mathrm{g} . \mathrm{H}}(4.6)$

dimana:

$\mathrm{K}_{1}=\phi=$ speed factor antara, diambil 0,46

$\mathrm{g} \quad=$ percepatan gravitasi sebesar $9,81 \mathrm{~m} / \mathrm{dt}^{2}$

$\mathrm{H}=\mathrm{H}_{\mathrm{ef}}=$ tinggi jatuh air neto sebesar $5,5 \mathrm{~m}$ maka :

$$
\begin{aligned}
\mathrm{U}_{1} & =0,46 \cdot \sqrt{2 \cdot 9,81 \cdot 5,5} \\
& =0,46 \cdot 10,3879 \mathrm{~m} / \mathrm{dt}=
\end{aligned}
$$

$4,778434 \mathrm{~m} / \mathrm{dt} \approx 4,78 \mathrm{~m} / \mathrm{dt}$

c. Diameter Rotor Pada Sisi Masuk ( $\left.D_{1}\right)$

Dari perhitungan tersebut diatas, dicari diameter rotor dengan rumus :

$$
\begin{aligned}
\mathrm{D}_{1} & =\frac{60 \cdot \phi \sqrt{2 \cdot \mathrm{g} \cdot \mathrm{h}}}{\pi \cdot \mathrm{n}}(4 \cdot 7) \\
& =\frac{60 \cdot 0,46 \sqrt{2 \cdot 9,81 \cdot 5,5}}{3,14 \cdot 175}=0,52176 \mathrm{~m} \\
\approx 0,52 \mathrm{~m} &
\end{aligned}
$$

d. Diameter Rotor Bagian Dalam $\left(\mathrm{D}_{2}\right)$

$$
\begin{aligned}
\mathrm{D}_{2} & =0,67 . \mathrm{D}_{1}(4 \cdot 8) \\
& =0,67 \cdot 0,52176 \mathrm{~m}=0,34957 \mathrm{~m} \\
& \approx 0,35 \mathrm{~m}
\end{aligned}
$$

e. Tinggi Sudu (a)

$$
\begin{aligned}
\mathrm{a} & =0,17 \mathrm{D}_{1}(4.9) \\
& =0,17 \cdot 0,52=0,0884 \mathrm{~m}
\end{aligned}
$$

\section{Perhitungan Panjang Runner (B)}

Panjang runner turbin dihitung dengan menggunakan rumus :

$$
\begin{aligned}
\mathrm{Q} & =f_{\mathrm{B}} \cdot \pi \cdot \mathrm{D}_{1} \cdot \mathrm{B} \cdot \mathrm{C}_{\mathrm{m} 1}(4 \cdot 10) \\
& =f_{\mathrm{B}} \cdot \pi \cdot \mathrm{D}_{1} \cdot \mathrm{B} \cdot \mathrm{C}_{1} \cdot \operatorname{Sin} \alpha_{1} \\
\mathrm{~B} & =\frac{\mathrm{Q}}{f_{\mathrm{B}} \cdot \pi \cdot \mathrm{D}_{1} \cdot \mathrm{C}_{1} \cdot \operatorname{Sin} \alpha_{1}}
\end{aligned}
$$

dimana dalam perencanaan menggunakan : 


$$
\begin{aligned}
& \mathrm{C}_{1}=\mathrm{K}_{\mathrm{C} 1} \cdot \sqrt{2 \cdot \mathrm{g} \cdot \mathrm{H}}=0,985 \cdot \sqrt{2 \cdot 9,81 \cdot 5,5} \\
& =10,232 \quad(4 \cdot 11) \\
& f_{\mathrm{B}}=\Phi / 360^{\circ}=90^{\circ} / 360^{\circ}=0,25 \\
& \alpha=16^{\circ} \\
& \mathrm{K}_{\mathrm{C} 1}=0,985 \\
& \mathrm{~B}=\frac{0.28}{0,25 \cdot 3,14 \cdot 0,52 \cdot 10,232 \cdot 0,2756} \\
& \mathrm{~B}=0,24324 \approx 0,24 \mathrm{~m}
\end{aligned}
$$

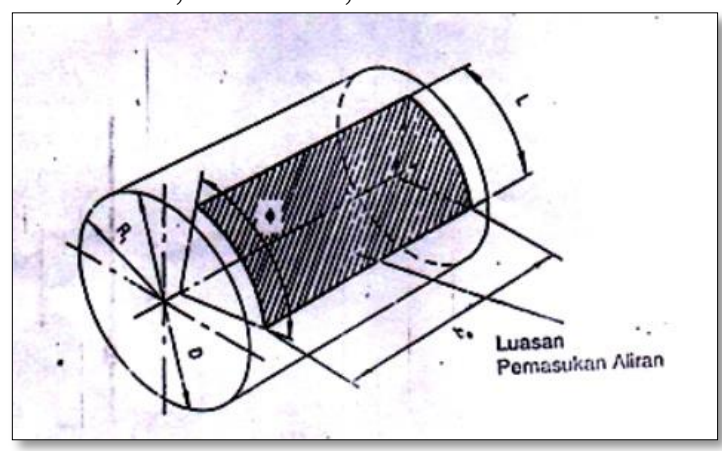

Gambar 3 Runner

Sumber:http://docplayer.info/97473434-Bab-iitinjauanpustaka.html. Diakses tanggal: 13 November 2019

\section{Perhitungan Panjang Busur (L)}

Panjang busur dapat dihitung menggunakan rumus :

$$
\begin{aligned}
& \mathrm{L}=f_{\mathrm{B}} \cdot \pi \cdot \mathrm{D}_{1} \quad(4.12) \\
& f_{\mathrm{B}}=90^{\circ} / 360^{\circ}=0,25 \quad \text { maka }: \mathrm{L}= \\
& \\
& 0,25 \cdot 3,14 \cdot 0,52=0,4082 \approx 0,41 \mathrm{~m}
\end{aligned}
$$

\section{Perhitungan Segitiga Kecepatan}

a. Parameter Saat Air Masuk Sudu Pada

\section{Tingkat I}

Dari hasil perhitungan diperoleh :

1. Kecepatan air masuk turbin $\mathrm{V}_{1}=10,232 \mathrm{~m} / \mathrm{dt}$

2. Diameter Runner bagian luar $\mathrm{D}_{1}=0,52 \mathrm{~m}$

3. Diameter Runner bagian dalam $\mathrm{D}_{2}=0,35 \mathrm{~m}$

4. Kecepatan Keliling Sisi Masuk Rotor/Kecepatan Tangensial $\left(\mathrm{U}_{1}\right)$ $\mathrm{U}_{1}=4,78 \mathrm{~m} / \mathrm{dt}$

5. Sudut masuk air $(\alpha)$

$$
\alpha_{1}=16^{\circ}
$$

Sehingga kecepatan Relatif air masuk sudu tingkat I :
$\mathrm{W}_{1}^{2}=\mathrm{V}_{1}^{2}+\mathrm{U}_{1}^{2}-2 \cdot \mathrm{V}_{1} \cdot \mathrm{U}_{1} \cdot \operatorname{Cos} \alpha_{1}(4.13)$

$\mathrm{W}_{1}^{2}=10,232^{2}+4,78^{2}-2.10,232.4,78$.

0,96126

$\mathrm{W}_{1}^{2}=33,513770$

$\mathrm{W}_{1}=\sqrt{33,513770}=5,789107 \mathrm{~m} / \mathrm{dt} \approx 5,79$

$\mathrm{m} / \mathrm{dt}$

Sudut $\beta_{1}: \operatorname{Cos} \beta_{1}=\frac{\mathrm{V}_{1} \cdot \operatorname{Cos} \alpha_{1}-\mathrm{U}_{1}}{\mathrm{~W}_{1}}(4.14)$

$$
=\frac{10,232 \cdot 0,96126-4,78}{5,79}=0,8731627
$$

$$
\beta_{1}=29,17^{\circ}
$$

b. Parameter Saat Air Keluar Sudu PadaTingkat I

1. Kecepatan tangensial air keluar sudu pada tingkat I adalah :

$$
\begin{aligned}
& \mathrm{U}_{2}=\frac{\pi \cdot \mathrm{D}_{2} \cdot \mathrm{n}}{60}(4 \cdot 15) \\
& =\frac{3,14 \cdot 0,35 \cdot 175}{60}=3,205416 \mathrm{~m} / \mathrm{dt}
\end{aligned}
$$

$\approx 3,21 \mathrm{~m} / \mathrm{dt}$

Pada perencanaan sudut $\beta_{2}=90^{\circ}$, sehingga sudut $\alpha_{2}$ dapat dicari seperti dibawah ini:

$\operatorname{Tg} \alpha_{2}=\frac{2 \cdot \operatorname{tg} \alpha_{1}}{\tau^{2}}(4.16)$

Dimana :

$$
\begin{aligned}
\tau & =\mathrm{D}_{2} / \mathrm{D}_{1} \\
& =0,35 / 0,52=0,673
\end{aligned}
$$

maka :

$\operatorname{Tg} \alpha_{2}=\frac{2 \cdot \operatorname{tg} 16}{0,673^{2}}(4.18)$

$\operatorname{Tg} \alpha_{2}=\frac{2.0,28674}{0,405}=1,416 \alpha_{2}$

$=54,769^{\circ}$

2. Kecepatan Absolut air keluar sudu pada tingkat I adalah :

$$
\begin{aligned}
& \mathrm{V}_{2}=\frac{U_{2}}{\operatorname{Cos} \alpha_{2}}(4.19) \\
& =\frac{3,205416}{\operatorname{Cos} 54,769^{\circ}} \\
& \mathrm{V}_{2}=5,557239 \mathrm{~m} / \mathrm{dt} \approx 5,56 \mathrm{~m} / \mathrm{dt}
\end{aligned}
$$

3. Kecepatan Relatif keluar sudu pada tingkat I adalah :

$$
\mathrm{W}_{2}=\sqrt{\mathrm{V}_{2}^{2}+\mathrm{U}_{2}^{2}-2 \cdot \mathrm{V}_{2} \cdot \mathrm{U}_{2} \cdot \operatorname{Cos} \alpha_{2}}
$$




$$
\begin{aligned}
& = \\
& \sqrt{5,56^{2}+3,205416^{2}-2 \cdot 5,56 \cdot 3,205416 \cdot 0,5768} \\
& =\sqrt{20,628702}=4,54188309 \mathrm{~m} / \mathrm{dt} \\
& \approx 4,60 \mathrm{~m} / \mathrm{dt}
\end{aligned}
$$

\section{c. Parameter Saat Air Masuk Sudu Pada Tingkat II}

Pada perhitungan ini, parameter kecepatan yang keluar pada tingkat I sama dengan parameter yang masuk pada tingkat II, sebagai berikut :

$$
\begin{aligned}
& \mathrm{V}_{3}=\mathrm{V}_{2}=5,56 \mathrm{~m} / \mathrm{dt} \\
& \alpha_{3}=\alpha_{2}=54,769^{\circ} \\
& \mathrm{W}_{3}=\mathrm{W}_{2}=4,60 \mathrm{~m} / \mathrm{dt} \\
& \beta_{3}=\beta_{2}=90 \\
& \mathrm{U}_{3}=\mathrm{U}_{2}=3,21 / \mathrm{dt}
\end{aligned}
$$

\section{Parameter Air Saat Keluar Pada Sudu \\ Tingkat II}

Ketentuan yang dipergunakan dalam melakukan perhitungan adalah sebagai berikut :

$\mathrm{W}_{4}=\mathrm{W}_{1}=5,79 \mathrm{~m} / \mathrm{dt}$

$\mathrm{U}_{4}=\mathrm{U}_{1}=4,78 \mathrm{~m} / \mathrm{dt}$

$\beta_{4}=\beta_{1}=29,17^{\circ}$

sehingga akan diperoleh :

$$
\begin{aligned}
& \mathrm{V}_{4}=\sqrt{\mathrm{U}_{4}^{2}+\mathrm{W}_{4}^{2}-2 \cdot \mathrm{U}_{4} \cdot \mathrm{W}_{4} \cdot \operatorname{Cos} \beta_{4}}(4 \cdot 21) \\
& =\sqrt{4,78^{2}+5,79^{2}-2 \cdot 4,78 \cdot 5,79 \cdot 0.873177} \\
& =\sqrt{8,04005} \\
& =2,83549 \mathrm{~m} / \mathrm{dt} \approx 2,84 \mathrm{~m} / \mathrm{dt} \\
& \quad \text { maka besar sudut } \alpha_{4} \\
& \operatorname{Cos} \alpha_{4}=\frac{\mathrm{V}_{4}^{2}+\mathrm{U}_{4}^{2}-\mathrm{W}_{4}^{2}}{2 \cdot \mathrm{V}_{4}+\mathrm{U}_{4}} \\
& \operatorname{Cos} \alpha_{4}=\frac{\mathrm{V}_{4}^{2}+\mathrm{U}_{4}^{2}-\mathrm{W}_{4}^{2}}{2 \cdot \mathrm{V}_{4}+\mathrm{U}_{4}}(4.22) \\
& =\frac{2,84^{2}+4,78^{2}-5,79}{2 \cdot 2,84 \cdot 4,78}=-0,0961348 \\
& \alpha_{4}=95 \cdot 517^{\circ}
\end{aligned}
$$

\section{Efisiensi Turbin $(\eta)$}

Efisiensi turbin Cross Flow dihitung dengan menggunakan rumus :

$(\eta)=\frac{\mathrm{U}_{1}\left(\mathrm{~V}_{1} \cdot \operatorname{Cos} \alpha_{1}-\mathrm{V}_{4} \cdot \operatorname{Cos} \alpha_{4}\right) \cdot 100 \%}{\mathrm{~g} \cdot \mathrm{H}}$

$$
\begin{aligned}
& =\frac{4,78\left(10,232 \cdot \operatorname{Cos} 16^{\circ}-2,84 \cdot \operatorname{Cos} 95 \cdot 517^{\circ}\right) \cdot 100 \%}{9,81 \cdot 5 \cdot 5}=89,55 \% \\
& \approx 90 \%
\end{aligned}
$$

Besar efisiensi turbin hasil perhitungan diperoleh sebesar $89,55 \%$, sedangkan efisiensi yang direncanakan sebesar 0,70. Dengan demikian dapat disimpulkan bahwa efisiensi dalam perencanaan memenuhi syarat, yaitu masih dibawah hasil perhitungan.

\section{Perancangan Sudu}

a. Jumlah Sudu (Z)

Jumlah sudu minimum sangat ditentukan oleh nilai $\mathrm{m}$. Jumlah sudu dapat ditentukan berdasarkan persamaan empirik :

$\mathrm{Z}=0,5 \mathrm{~m}+15 \rightarrow$ untuk $\mathrm{m}=6-35(4.24)$

Pada perancangan ini jumlah sudu ditetapkan $m=10$, sehingga :

$$
\begin{aligned}
& \mathrm{Z}=0,5.10+15=5+15=20 \text { buah } \\
& \text { Derajad pembagian sudu turbin Cross } \\
& \text { Flow sebesar : } \\
& =360^{\circ} / \mathrm{Z} \\
& =360^{\circ} / 20=18^{\circ}
\end{aligned}
$$

b. Bahan Sudu

Bahansudu pada perancangan ini dipilih dari baja SAE 1015 dengan data sebagai berikut :

Beratjenis plat $(\delta)=0,0078 \mathrm{~kg} / \mathrm{cm}^{3}=$ $7,8 \mathrm{~kg} / \mathrm{dm}^{3}$

Tegangan maksimum $\left(\sigma_{\mathrm{mak}}\right)=6000$ $\mathrm{kg} / \mathrm{cm}^{2}$

Tegangan bengkok $\left(\sigma_{\mathrm{b}}\right)=4,2 \times 10^{4}$ $\mathrm{kg} / \mathrm{cm}^{2}$

Tebal plat $(\mathrm{t})=4 \mathrm{~mm}$

c. Volume TiapSudu

Volume sudu dapat dihitung dengan rumus :

$$
\mathrm{V}=\mathrm{t} . \mathrm{lb} . \mathrm{B}
$$

dimana :

$$
\begin{aligned}
& \mathrm{t}=4 \mathrm{~mm} \\
& \mathrm{lb}=\text { panjang busur }(58,99 \mathrm{~mm}) \\
& \mathrm{b}=\text { panjang sudu }(240 \mathrm{~mm})
\end{aligned}
$$

Maka : 
$\mathrm{V}=4 \times 58,99 \times 240=56630,4 \mathrm{~mm}^{3}=$

$5,6630 \times 10^{-4} \mathrm{dm}^{3}$

d. Berat Sudu

Berat tiap sudu dihitung dengan rumus :

$$
\begin{aligned}
\mathrm{G}_{\mathrm{s}} & =\mathrm{t} . \mathrm{lb} \cdot \mathrm{B} \cdot \partial(4 \cdot 27) \\
& =\mathrm{V} \cdot \partial=5,6630 \times 10^{-4} \times 7,8 \\
& =0,0044 \mathrm{~kg}
\end{aligned}
$$

Jadiberatsudu total adalah :

$$
\begin{aligned}
\mathrm{G}_{\mathrm{t}} & =\mathrm{G}_{\mathrm{s} .} \mathrm{Z} \\
& =0,0044 \times 20=0,088 \mathrm{~kg}
\end{aligned}
$$

e. Berat Runner

Tebaldari plat disc direncanakan $\mathrm{t}=9 \mathrm{~mm}$, jumlahnya 2 buah dengan pemasangan disc di las.

Berat Disc :

$\mathrm{G}_{\mathrm{d}}=\pi / 4 . \mathrm{D}^{2} \cdot \mathrm{t} \cdot \partial \cdot 2$

Dimana :

$\mathrm{D}=$ diameter luar runner $(52 \mathrm{~cm})$

$\mathrm{t}=$ tebal plat disc $(0,9 \mathrm{~cm})$

$\partial=$ berat jenis bahan $\left(0,0078 \mathrm{~kg} / \mathrm{cm}^{3}\right)$

sehingga :

$\mathrm{G}_{\mathrm{d}}=\pi / 4 \times(52)^{2} \times 0,9 \times 0,0078.2$

$=30,974 \mathrm{~kg}$

Berat runner keseluruhan adalah :

$\mathrm{G}_{\mathrm{r}}=$ Berat sudu + Berat disc (4.30) $=0,088+30,974=31,062 \mathrm{~kg}$

Karena adanya pengelasan antara disc dan sudu maka runner dianggap $\mathrm{G}_{\mathrm{r}}=35 \mathrm{~kg}$.

f. Kekuatan Sudu

Pada perencanaan bahan sudu diatas adalah baja karbon menengah, dan setelah mengetahui berat dari setiap sudu maka tegangan bengkok yang terjadi dapat diketahui dengan rumus :

$$
\sigma_{\mathrm{b}}=\frac{\mathrm{M}_{\mathrm{b}}}{\mathrm{W}_{\mathrm{b}}}(4.31)
$$

dimana :

$\mathrm{M}_{\mathrm{b}}=$ Momen bengkok

$\mathrm{M}_{\mathrm{b}}=\frac{\mathrm{G}_{\mathrm{s}} \cdot \mathrm{b}}{4}$ dimana :

$\mathrm{G}_{\mathrm{s}}=$ berat tiap sudu $(0,0044 \mathrm{~kg})$

$\mathrm{b}=$ panjang sudu $(240 \mathrm{~cm})$

$$
=\frac{0,0044 \times 240}{4}=0,264 \mathrm{~kg} \cdot \mathrm{cm}
$$

$\mathrm{W}_{\mathrm{b}}=$ momen tahanan terhadap bengkok
$\mathrm{W}_{\mathrm{b}}=1 / 6 \cdot \mathrm{b} \cdot \mathrm{h}^{2}$

dimana:

$\mathrm{b}=\mathrm{lb}=$ panjang busur $(5,899 \mathrm{~cm})$

$\mathrm{h}=\mathrm{t}=$ tebal plat $(0,4 \mathrm{~cm})$

Maka :

$\mathrm{Wb}=1 / 6 \times 5,899 \times 0,4^{2}=0,1573 \mathrm{~cm}^{3}$

Sehingga : $\quad \sigma_{b}=\frac{M_{b}}{W_{b}}$

$$
=\frac{0,264}{0,1573}=1,678 \mathrm{~kg} / \mathrm{cm}^{2}
$$

Tegangan yang terjadi pada sudujauh di bawah tegangan bengkok bahan yang diijinkan $\left(4,2 \times 10^{4} \mathrm{~kg} / \mathrm{cm}^{2}\right)$, maka pemilihan bahan aman.

g. Diameter Kelengkungan Sudu Pada gambar diatas, adalah contoh cara menggambar kelengkungan sudu. Urutan pengambarannya adalah sebagai berikut :

1. Membuat segitiga AOB dengan sudut $\mathrm{AOB}=\beta_{1}+\beta_{2}$

2. Membuat garis $C D$ dengan sudut $\mathrm{OCD}=\beta_{2}$

3. Membuat garis $A D$ dengan sudut $\mathrm{OAD}=\beta_{1}$

Titik D adalah titik pusat kelengkungan sudu

h. Panjang Busur Sudu (lb)

Data hasil perhitungan yang telah diperoleh data sebagai berikut :

$$
\begin{aligned}
& \beta_{1}=29,17^{\circ} \\
& \beta_{2}=90^{\circ} \\
& D_{1}=0,52 \mathrm{~m}---\rightarrow R_{1}=26 \mathrm{~cm} \\
& D_{2}=0,35 \mathrm{~m}--\rightarrow R_{2}=17,5 \mathrm{~cm}
\end{aligned}
$$

Data tersebut diatas dipergunakan untuk menghitung :

$$
\begin{aligned}
& \text { a. Panjang C (Gambar 6) } \\
& \begin{aligned}
\mathrm{C}= & \sqrt{\mathrm{R}_{1}{ }^{2}+\mathrm{R}_{1}{ }^{2}-2 \cdot \mathrm{R}_{1} \cdot \mathrm{R}_{2} \cdot \operatorname{Cos}\left(\beta_{1} \cdot+\beta_{2}\right)}(4.32) \\
= & \sqrt{26^{2}+17,5^{2}-2 \cdot 26 \cdot 17,5 \cdot \operatorname{Cos}\left(29,17^{0} \cdot+90^{0}\right)} \\
& =\sqrt{0,14257} \approx 0,377 \mathrm{~m}
\end{aligned}
\end{aligned}
$$

b. Sudut $\varepsilon$

$$
\begin{aligned}
\varepsilon= & \operatorname{arc} \cdot \operatorname{Sin} \frac{\left[R_{2} \cdot \operatorname{Sin}\left(\beta_{1}+\beta_{2}\right)\right]}{\mathrm{C}}(4 \cdot 33) \\
& =\operatorname{arc} \cdot \operatorname{Sin} \frac{\left[0,1750 \cdot \operatorname{Sin}\left(29,17^{\circ}+90^{\circ}\right)\right]}{0,337} \\
& =\text { Arc. } \operatorname{Sin} 0,4534=26,96^{\circ}
\end{aligned}
$$


c. Sudut $\xi$

$$
\xi=180^{\circ}-
$$$$
\left(\beta_{1}+\beta_{2}+\varepsilon\right)
$$

$4)=180^{\circ}-\left(119,17^{\circ}+26,96^{\circ}\right)=$ $33,87^{\circ}$

d. Sudut $\theta$

$$
\begin{aligned}
& \theta=\left(\beta_{1}+\beta_{2}\right)-\left(180^{\circ}-2 . \xi\right) \\
& 35) \\
& =(29.17+90)^{\circ}-\left(180^{\circ}-2 * 33,87^{\circ}\right) \\
& =6,91^{\circ}
\end{aligned}
$$

e. Panjang $\mathrm{d}$

$$
\begin{aligned}
\mathrm{d} & =\frac{\mathrm{R}_{1} \cdot \operatorname{Sin} \theta}{2 \operatorname{Sin}\left(180^{\circ}-\xi\right)}(4 \cdot 36) \\
& =\frac{0,26 \cdot \operatorname{Sin}, 6,91}{2 \operatorname{Sin}\left(180^{\circ}-33,87^{\circ}\right)}=0,028 \mathrm{~m}
\end{aligned}
$$

f. Sudut kelengkungan sudu $\delta$

$$
\begin{aligned}
& =180^{\circ}-2 \cdot\left(\left(\beta_{1}+\varepsilon\right)\right. \\
& (4.37) \\
& =180^{\circ}-2 \cdot\left(29,17^{\circ}+26,96^{\circ)}=67,74\right. \\
& \text { o }
\end{aligned}
$$

g. Sudut jari-jari kelengkungan sudu (rb)

$$
\begin{aligned}
\mathrm{rb} & =\frac{\mathrm{d}}{\operatorname{Cos}\left(\beta_{1}+\varepsilon\right)}(4.38) \\
& =\frac{0,028}{\operatorname{Cos}(29,17+26,96)}=0,0502 \mathrm{~m}
\end{aligned}
$$

h. Jarak jari-jari kelengkungan sudu (rp)

$$
\begin{aligned}
& \mathrm{rp} \\
& \begin{aligned}
= & \sqrt{\mathrm{rb}^{2}+\mathrm{R}_{1}^{2}-2 \mathrm{rb} \cdot \mathrm{R}_{1} \cdot \operatorname{Cos} \beta_{1}}(4 \cdot 39) \\
& =\sqrt{0,050^{2}+0,26^{2}-2 \cdot 0,050 \cdot 0,26 \cdot 0,873177} \\
& =\sqrt{0,0526}=0,2293 \mathrm{~m} \text { (diukur }
\end{aligned} \\
& \text { dari pusat diameter runner) }
\end{aligned}
$$

i. Panjang busur sudu (lb)

$$
\mathrm{lb}=2 . \pi . \mathrm{rb} . \delta / 360^{\circ}
$$

$$
=2 \cdot 3,14 \cdot 0,050 \cdot 67 \cdot 64^{\circ} / 360^{\circ}
$$$$
=0,05899 \mathrm{~m}
$$

\section{PerancanganPoros Turbin}

Diameter poros dapat dicari dengan menggunakan persamaan :

$$
\tau_{\mathrm{e}}=\frac{\pi}{16} \cdot \tau \cdot \mathrm{d}^{3}
$$

dimana : $\tau_{\mathrm{e}}=$ torsi ekivalen yang bekerja pada poros $(\mathrm{Nmm})$

$\tau=$ tegangan geser bahan poros $\left(\mathrm{N} / \mathrm{mm}^{2}\right)$

$\mathrm{d}=$ diameter poros $(\mathrm{m})$

1. Torsi yang dipindahkan oleh poros $(\mathrm{T})$ :

$$
\begin{aligned}
& \mathrm{T}=\frac{60 . P}{2 . \pi \cdot \mathrm{N}}(4.42) \\
& =\frac{60.1057}{2.3 \cdot 14 \cdot 175}=57,707 \mathrm{Nm}
\end{aligned}
$$

2. Gaya tangensial $\left(\mathrm{F}_{\mathrm{t}}\right)$ :

$$
\begin{aligned}
\mathrm{F}_{\mathrm{t}} & =\frac{2 . T}{D_{1}}(4.43) \\
& =\frac{2.57,707}{0.52}=221,95 \mathrm{~N}
\end{aligned}
$$

3. Gaya Normal $\left(F_{n}\right)$ :

$$
\begin{aligned}
\mathrm{F}_{\mathrm{n}} & =\frac{F_{t}}{\operatorname{Cos} \beta}(4.44) \\
& =\frac{221,95}{\operatorname{Cos} 30}=\frac{221,95}{0,8660} \\
& =256,293 \mathrm{~N}
\end{aligned}
$$

4. Momen Lentur (M) :

Momen lentur yang terjadi ditentukan dengan menggunakan persamaan $\mathrm{M}=\frac{F_{n} \cdot L}{4}(4.45)$

dimana :

$\mathrm{L}=$ Panjang poros atau jarak antara bantalan yang menumpu poros

$$
\begin{aligned}
\mathrm{L} & =\mathrm{B}+\mathrm{a} \\
& =0,24+0,0884=0,3284 \mathrm{~m}
\end{aligned}
$$

sehingga :

$$
\begin{aligned}
& \mathrm{M}=\frac{F_{n} \cdot L}{4}(4 \cdot 47) \\
= & \frac{256,293 \cdot 0,3284}{4}=21,041 \mathrm{Nm}
\end{aligned}
$$

5. Torsi Ekivalen $\left(\tau_{\mathrm{e}}\right)$ :

$$
\begin{aligned}
\tau_{\mathrm{e}} & =\sqrt{\mathrm{M}^{2}+\mathrm{T}^{2}}(4.48) \\
& =\sqrt{21,041^{2}+57,707^{2}}=61,423 \mathrm{Nm}
\end{aligned}
$$

Bahan Poros :

Bahan poros diambil dari ST 60 dengan tegangan geser $\left(\tau=45 \mathrm{~N} / \mathrm{mm}^{2}\right.$

Sehingga besar diameter poros :

$\mathrm{d}^{3}=\frac{16 . \tau_{e}}{\pi . \tau}(4.49)$ 


$$
\begin{aligned}
& =\frac{16 \cdot 61,423}{3,14 \cdot 45}=6955,18 \\
d & =\sqrt[3]{6955,18}=19,0883 \mathrm{~mm}
\end{aligned}
$$

Karena beban yang diterima poros masih ditambah berat Runner, berat poros dan gaya tarik sabuk $\mathrm{V}$, maka diameter poros diambil $\mathrm{d}=50 \mathrm{~mm}$.

\section{Perancangan Bantalan}

1. Jenis dan ukuran bantalan

Bantalan yang dipergunakan adalah bantalan Bola. Dari tabel bantalan SKF halaman 138 didapat data sebagai berikut : Bantalan SKF type 2RS1 dengan dua seals :
a. Diameter Inner
$\mathrm{d}=50 \mathrm{~mm}$
b. Diameter Outer
$\mathrm{D}=90 \mathrm{~mm}$
c. Lebar bantalan
$\mathrm{B}=20 \mathrm{~mm}$
d. Beban dinamik
$\mathrm{C}=35.100 \mathrm{~N}$
e. Beban Statik
$\mathrm{C}_{0}=19.600$
f. Kecepatan putaran maksimum $\mathrm{N}=4.800 \mathrm{rpm}$
g. Massa Bantalan $=0,46 \mathrm{~kg}$
h. Kode $=6210-2$ RS 1

2. Umur Bantalan :

Umur bantalan dapat ditentukan dengan menggunakan persamaan :

$$
\mathrm{L}_{10 \mathrm{~h}}=\frac{1000000}{60 N}\left[\frac{C}{P}\right] P(4.50)
$$

$$
\begin{aligned}
& \text { dimana : } \\
& \mathrm{N}=\operatorname{kecepatan} \text { putaran }(\mathrm{rpm}) \\
& \mathrm{C}=\operatorname{beban} \operatorname{dinamik}(\mathrm{N})
\end{aligned}
$$

$\mathrm{P}=$ ekivalen beban dinamik $(\mathrm{N})$

$\mathrm{P}=$ konstanta, untuk bantalan bola $\mathrm{p}=3$ :

Beban yang bekerja pada bantalan dianggap radial saja yaitu :

$\mathrm{P}=\mathrm{Fn}+$ berat rotor + berat poros + gaya

tarik sabuk V

Berat rotor diambil $150 \mathrm{~N}$

Berat poros $=\pi \cdot \mathrm{r}^{2} . \mathrm{L}$. $\rho_{\text {baja }}(4.51)$

$=3,14 \cdot 0,025^{2} \cdot 0,3284.7850$

$=5,05920 \mathrm{~kg}=50,5920 \mathrm{~N}$

sehingga
$\mathrm{P}=256,293+150+50,5920+291,685=$

$748,57 \mathrm{~N}$

Umur bantalan $\mathrm{L}_{10 \mathrm{~h}}=\frac{1.000 .000}{60.175} \cdot\left[\frac{35100}{748,57}\right]^{3}$

$=981.826,6$ jam $=112,0806$ tahun

$\approx 113$ tahun

Catatan :

Umur bantalan tersebut adalah jika semua dalam kondisi ideal.

\section{Perancangan Kopling}

Kopling yang direncanakan adalah type Flange Coupling dari bahan besi cor. Tegangan geser untuk baut dan material pasak $=40 \mathrm{Mpa}$

Tegangan tekan untuk baut dan pasak $=80$ Mpa

Tegangan geser untuk baut dari besi cor $=8$ Mpa

\section{Perbandingan Benefit dengan Cost}

$$
\frac{B}{C}=\frac{19 \cdot 008 \cdot 000,00}{24 \cdot 204 \cdot 113,34}=0,79
$$

Karena

$$
\frac{B}{C}=<1, \text { maka proyek PLTMH tersebut }
$$

dinilai tidak ekonomis.

\section{Keuntungan Bersih (Net Benefit)}

Keuntungan bersih adalah : Jumlah

Benefit dikurangkan pembiayaan (Cost) :

$$
\begin{array}{lr}
\text { Rp. } & 19.008 .000,00 \\
\text { Rp. } & 24.204 .113,34 \\
\hline \text { Rp. } & 5.196 .113,34
\end{array}
$$

Karena diperhitungkan antara pemasukan dengan pengeluaran setiap tahunnya bernilai kurang, maka jika projek ini dilaksanakan tidak akan menghasilkan keuntungan.

Maka proyek PLTMH ini hanya cocok dilaksanakan apabila dana yang dipergunakan bersifat bantuan atau hibah atau dengan kata lain tidak harus mengembalikan pinjaman.

\section{PENUTUP}

Setelah mengadakan penelitian dengan melakukan studi kelayakan dan perancangan serta 
implementasi turbin pada proyek mikrohidro, seperti yang terdapat pada hasil penelitian, didapatkan kesimpulan bahwa:

1. Pembanguan PLTMH di Desa Girikerto kecamatan Turi kabupaten Sleman secara teknis memenuhi persyaratan layak bangun, namun tidak demikian bila dikaji secara ekonomis. Akan tetapi, karena kemanfaatannya bagi masyarakat sangat besar, maka pembangunan PLTMH ini layak untuk dilaksanakan.

2. Untuk menghasilkan daya yang optimal dan mendapatkan efisiensi yang maksimal maka turbin air tipe cross flow sangat tepat untuk digunakan.

3. Studi kelayakan dan perancangan serta implementasi turbin ini dapat digunakan sebagai acuan proyek mikrohidro dikabupaten Sleman. Meskipun studi kelayakan hanya dilakukan pada aspek teknik dan perancangan hanya dilakukan pada karakteristik turbin secara garis besarnya saja, serta implementasi pada pengerjaan awalnya dan selanjutnya diserahkan pada pimpinan proyek.

4. Dari sisi sosial, dampak pembangunan PLTMH didesa Girikerto ini terhadap generasi muda daerah tersebut sangat menguntungkan, yakni sebagai sarana penelitian dan pengembangan untuk pemakaian teknologi ramah lingkungan.

\section{UCAPAN TERIMA KASIH}

1. Bupati Ogan Komering Ulu bapak Drs. H. Kuryana Azis

2. Wakil Bupati Ogan Komering Ulu bapak Drs. Johan Anuar, SH., MM.

\section{REFERENSI}

[1] Aris munandar, Wiranto., 1997. Penggerak Mula Turbin, ITB, Bandung.

[2] BPS dan BAPPEDA Kabupaten Sleman, Kabupaten Sleman dalam angka 2001.

[3] BPS dan BAPPEDA Kabupaten Sleman, Kecamatan Turi dalam angka 2001.
[4] Fritz Dietzel., Dakso Sriyono.,Turbin Pompa dan Kompressor, Penerbit Erlangga. Jakarta, 1988.

[5] Maryono, Agus.,Muth, W., Eisenhauer.,2002. Hidrolika Terapan, Pradnya Paramita, Jakarta.

[6] Sutikno, Djoko. 1992. Turbin Cross Flow (Studi Experimental). Jurnal Fakultas Teknik Universitas Brawijaya. Vol.I.No.1 Agustus 1992

[7] Soeharto, Iman., 2002. Studi Kelayakan Proyek, Jakarta: Erlangga.

[8] Yuliati, Sri Handaru dan Sartono, R. Agus., Studi Kelayakan. Departemen Pendidikan dan Kebudayaan, Universitas Terbuka, 1989.

[9] http://www.waterwheel factory.com/ossberg.htm, water wheel factory your water wheel solution The Cross Flow Turbine.Diakses tanggal: 13 November 2019

[10] http://home.carolina.rr.com/unclejoe/contr uction. html, Banki Cross Flow Turbine Construction. Diakses tanggal: 13 November 2019

[11] Sumber:https://www.slideshare.net/Birink/ makalah-prime-mover. Diakses tanggal: 13 Desember 2019

[12] Sumber: http://docplayer.info/97473434Bab-ii-tinjauanpustaka.html. Diakses tanggal: 13 November 2019

[13] Sumber:https://www.slideshare.net/Birink/ makalah-prime-mover. Diakses tanggal: 13 November 2019 